\title{
Household Formation, Female Labor Supply and Savings
}

\author{
Hans Fehr* \\ University of Wuerzburg, \\ Netspar and CESifo
}

\author{
Manuel Kallweit \\ University of Wuerzburg
}

\author{
Fabian Kindermann \\ University of Wuerzburg \\ and Netspar
}

April 2012

\begin{abstract}
The present paper aims at quantifying the impact of changing family structures on labor supply and savings in western societies. For this reason we develop a dynamic general equilibrium model with both genders, which takes into account changes of the marital status as a stochastic process. Individuals respond to these shocks by adjusting savings, market labor supply and home production. Our simulation model is calibrated to the German economy.

The results indicate that changes in household formation might at least partly explain the reallocation of male and female labor market participation observed during the last decades. In addition, we find a significant negative impact on capital accumulation.
\end{abstract}

JEL Classifications: J12, J22

Keywords: marital risk, home production, stochastic general equilibrium, life cycle model

An earlier version of this paper circulated as "Marital risk, family insurance, and public policy". The paper was presented at the Netspar Pension Workshop in Stockholm, the FNA Graduiertenkolloquium in Berlin, the annual conference of the Verein für Socialpolitik in Magdeburg, the 6th Norwegian-German Seminar on Public Economics in Munich, the Ausschuss für Bevölkerungsökonomik in Bamberg, the University of Augsburg, the Alpine Population Conference in La Thuile and the 6th European Workshop on Labour Markets and Demographic Change in Vienna. We thank Karl Ove Aarbu, Johann Brunner, Alexia Fürnkranz-Prskawetz, Alfred Maussner, Lex Meijdam and other seminar participants for helpful comments. Financial support from NETSPAR and the Fritz Thyssen Stiftung is gratefully acknowledged.

${ }^{*}$ Corresponding author:

Address: University of Wuerzburg, Sanderring 2, 97070 Wuerzburg, Germany

Email: Email: hans.fehr@uni-wuerzburg.de 


\section{Introduction}

Almost all western societies are currently experiencing an unprecedented two-dimensional demographic transition. On the one side, low fertility and reduced mortality rates change the age structure of the population. On the other side, declining marriage and increasing divorce rates radically alter the traditional family structure within cohorts. Whereas in the past long-term marriage combined with gender specialization was a near-universal adult experience, only a minority follows this role model nowadays.

While numerous studies have already evaluated the economic consequences of population aging, much less research has focussed on the impact of the changing household structure for various economic aggregates. Changes in the number of couples and singles in an economy will alter the respective income distribution as well as the structure of tax payments and public transfers. In addition, precautionary behavior will be adjusted, since families offer an (incomplete) insurance contract against lifespan (Kotlikoff and Spivak, 1981) and income risk (Attanasio et al., 2005). Consequently, the actual and the perceived future household structure will affect life-cycle labor supply, consumption and savings behavior which in turn may have severe effects on labor and capital markets.

The present study attempts to quantify such macroeconomic repercussions of the changing family structure. We concentrate on Germany, since it experienced in the last decades a transformation of household structures which is typical for Western societies. In addition, time allocation in Germany seems to be a mixture of that in typical European countries and in the U.S. Finally, Germany is interesting in this context, since its income tax system is very specific with respect to family status. For our quantitative analysis we develop a two-sex life-cycle family model with endogenous labor supply, which accounts for income, lifespan and marital risk and distinguishes between market work and home production. Our approach is related to several strands of the recent literature with calibrated models. First, it builds on Rogerson (2009) and Olovsson (2009) who analyze labor supply issues in models with home production. Second, it is linked to the large literature that tries to explain the long run changes in labor supply of married women such as Greenwood et al. (2005), Olivetti (2006), Attanasio et al. (2008), Kaygusuz (2010) or Guner et al. (2012). Finally, it is connected to family models such as Caucutt et al. (2002), Chade and Ventura (2002), or Greenwood and Guner (2009) which either deal with marriage issues or concentrate on the relationship between fertility and labor supply decisions. We abstract from endogenous marriage and fertility, but model changes in marital status as exogenous shocks. We then focus on the interaction between marriage and divorce rates and labor supply and savings. Various studies have already introduced marital risk in stochastic life-cycle simulation models. Love (2010) includes marriage and divorce risk in a partial equilibrium model with labor income and investment uncertainty in order to analyze optimal portfolio choice. Our approach mainly builds on the general equilibrium studies of Domeij and Klein (2002), Hong and Rios-Rull (2007) as well as Cubeddu and Rios-Rull (2003) who extend the standard overlapping generations model in the Auerbach and Kotlikoff (1987) tradition by explicitly accounting for marital transitions during the life-cycle. Domeij and Klein (2002) as well as Hong and Rios- 
Rull (2007) keep marriage patterns constant and analyze the long-run impact of social security privatization in Sweden and the US. Cubeddu and Rios-Rull (2003) study the long-run consequences of alternative marriage transitions for aggregate savings. They find that rising divorce risk increases precautionary savings but the aggregate savings impact depends on specific institutional features such as asset splitting rules, divorce costs and remarriage patterns.

Our study extends this approach in various directions. First, while Cubeddu and Rios-Rull (2003) abstract from labor supply issues, our model allows for endogenous labor supply and household production of both partners of the marriage. Second, we introduce income and lifespan uncertainty as well as mating across education types in order to capture and isolate the insurance provision of marriages. Finally, we model a detailed government sector with progressive income taxes and joint filing in order to analyze the interaction between the tax system and the household's labor supply and saving decision. Starting from an initial longrun equilibrium reflecting current German marriage and divorce probabilities, we simulate what would have happened to the economy, if Germany still had household structures as in the 1970s. Our quantitative results indicate that the ongoing transformation of household structures in Germany may explain a significant fraction of the past increase (decline) in female (male) labor market participation. Our model also indicates that aggregate savings are negatively affected by these demographic developments.

The next section documents recent changes in household formation in Europe and Germany and discusses previous studies analyzing its impact on economic activity. Section 3 describes the structure of the simulation model, while section 4 explains the calibration and simulation approach. Finally, section 5 presents the simulation results and the last section offers some concluding remarks.

\section{Changes in household formation and economic activity}

Various statistical concepts are available which measure the dynamics of marital transitions and household formation. In Figure 1 we compare changes in crude marriage and divorce rates between 1970 and 2009 for some selected European countries. The crude marriage (divorce) rate is the number of marriages (divorces) formed each year as a ratio of 1000 people. Both measures only account for official changes in formal partnerships, i.e. the marriage rate disregards formal cohabitation contracts and informal partnerships while the divorce rate neglects separations where partners remain married officially and breakdowns of unofficial partnerships. ${ }^{1}$

The left part of Figure 1 illustrates the significant decline in the crude marriage rate since

1 There is a rising proportion of cohabiting couples (i.e. larger than $10 \%$ of all couple households) in most European countries. However, despite cohabitation may have been used as substitute for marriage in the past, it does not cause the same economic consequences as marriage. Therefore it can be disregarded in the following discussion. 
1970, which took place in almost all European countries. The downward trend was especially substantial in countries such as the Czech Republic, Finland, the Netherlands and Portugal where in 1970 marriage rates were exceptionally high, while it was limited in Denmark or Sweden where marriage rates were already relatively low. While marriage rates differed substantially across European countries 35 years ago, it seems that they have converged to roughly 5.0 marriages per 1000 inhabitants in recent years. The decline of the marriage rates could be interpreted more clearly if the age-specific first marriage rates of a specific year are aggregated in order to indicate the probability of marriage of a person during his or her lifetime. Whereas for European women this so-called "total first marriage rate" was above 90 percent during the 1960s, nowadays only 58 percent of women get married during their lifetime in Europe, see CEP (2006).

Figure 1: Crude marriage and divorce rates in Europe
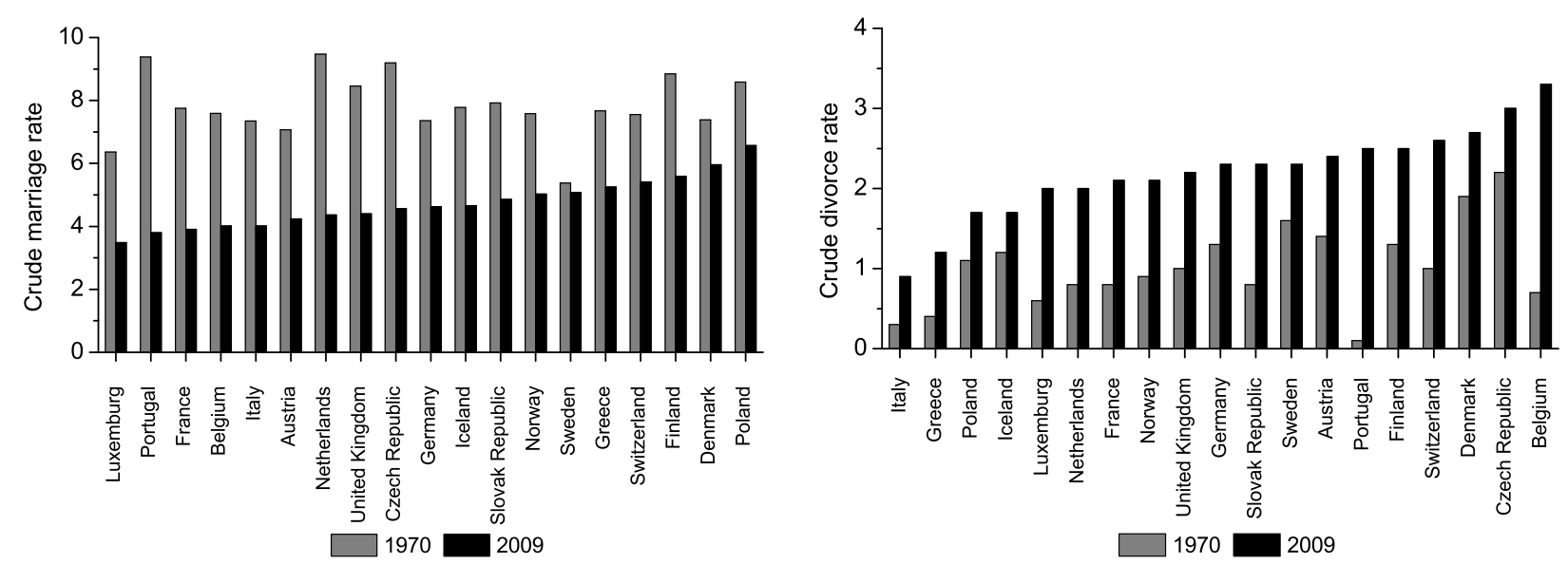

Source: OECD (2011a)

But not only marriage rates have decreased, also divorce rates have increased significantly in all countries. As shown in the right part of Figure 1, cross-national differences still remain important in 2009. While low divorce rates still prevail in countries such as Greece, Italy or Poland, countries like Belgium, the Czech Republic and Denmark stand out with three times higher numbers. Overall, the average European total divorce rate, which indicates the probability of a married person being divorced, has increased from roughly 10 percent to 32 percent in 2004, see CEP (2006). Compared to Europeans, Americans marry and divorce at higher rates, but the time trend is quite similar, see Stevenson and Wolfers (2007).

During the same period, female employment and labor force participation has increased strongly in most OECD countries. While in 1970 only about 45 percent of women in OECD countries were employed in the labor market, employment rates in year 2008 amounted to 61 percent, see OECD Database. In order to get a first intuition that family formation may have an impact on female employment rates, Figure 2 compares cross-sectional data of a family formation indicator and female labor market participation rates. Obviously there exists a clear negative relationship, which intuitively reflects the fact that married women mainly work at home while single women work more on the labor market. 
Figure 2: Family formation and female labor market participation

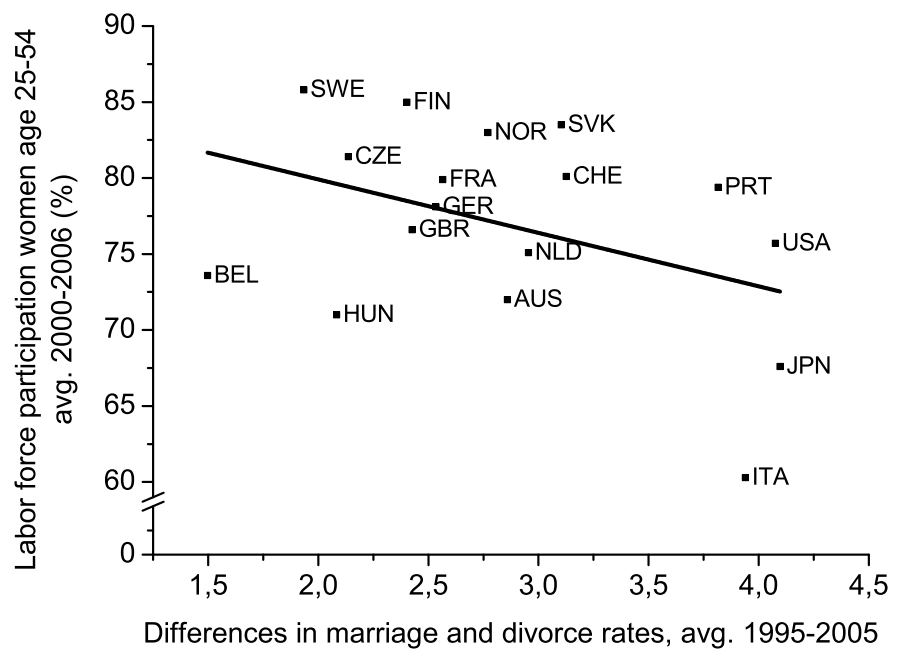

Source: own calculations based on OECD (2009) and OECD (2011b)

However, the connection between female labor supply and marriage and divorce risk is much more complex, so that various studies have explored this relationship in the past. Already Johnson and Skinner (1986) argued in the context of a static household model that increased divorce probabilities have a significant positive impact on female participation rates in the USA. Stevenson (2008) confirms this finding by analyzing the past changes in divorce law (which increased marriage instability). In principle, marriage and divorce can be viewed as costly events, so that increased marital risk induces - similarly as rising income risk - precautionary behavior. Therefore, the positive relationship between divorce probability and female labor supply is significant in the intertemporal labor supply model of Papps (2006), where married partners both choose their labor supply simultaneously. Surprisingly, this study also finds that higher marriage probabilities have a positive effect on singles' labor supply. Especially for women who expect to marry a partner with higher income, one would expect the opposite. But - as suggested by Papps (2006, p. 30) - maybe these women already take into account the possible divorce after marriage.

In the recent past, Germany has experienced very similar changes in martial transition rates as well as female labor market participation. As shown in the left part of Figure 3, crude marriage rates declined since 1970 from 7.4 to currently 4.6 marriages per 1000 inhabitants while during the same time span divorce rates roughly doubled. ${ }^{2}$ The right part of Figure 3 documents that since 1970 the labor market participation of women has also increased dramatically from 46.3 to 65.2 percent in 2008. During the same time span, participation rates of males in Germany have declined or remained stable.

The literature cited above explains the large changes in female employment with innovations in household production technologies (Greenwood et al., 2005), rising educational

2 The two interruptions in the divorce rate trend are due to changes in divorce law (1975) and the German reunification (1990). 
Figure 3: Family formation and female labor supply in Germany 1970-2005
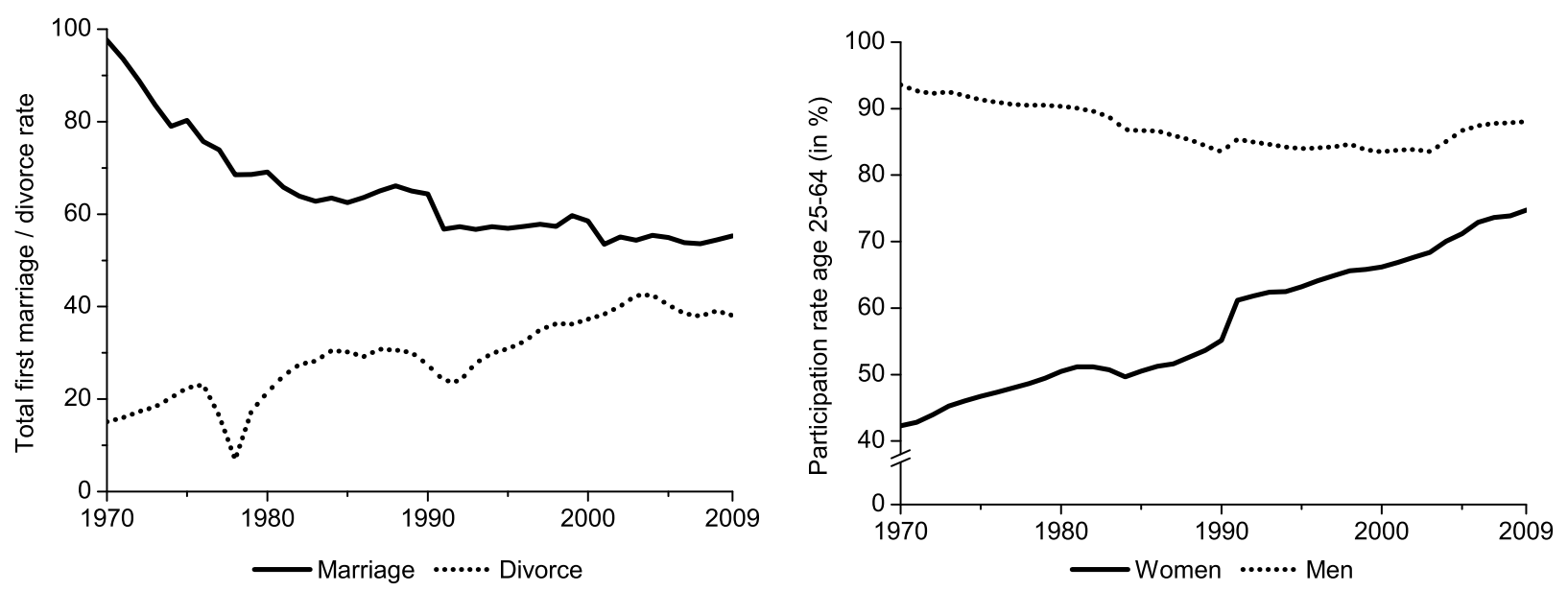

Source: $\mathrm{BiB}(2008)$ and OECD (2011b)

attainment of females (Olivetti, 2005), decreases in child care cost (Attanasio et al., 2008) or changes in the tax system (Kaygusuz, 2010; Guner et al., 2012). Of course, changes in household structures are also typically brought forward as an explanation, but the exact mechanism which is at work has not been analyzed in a household model so far. The issue is complicated by the fact that changes in household structures and rising marital risk may affect labor supply and savings simultaneously, while the direction of the savings effect is not clear at all. On the one hand, since marriage is a risk-reducing institution (Attanasio et al., 2005), precautionary savings should be higher for single households than for married couples. In addition, Glazer (2008) points out that under-saving may be a problem in a noncooperative family context, where savings by one member may induce additional consumption by another member. On the other hand, there also are economies of scale in consumption (i.e. shared cost for housing, food preparation etc.), so that married couples could achieve the same utility with less combined expenditure than the sum of their individual consumption if living apart. These economies of scale induce a positive wealth effect but also a price effect, since specific consumption items such as housing may become more expensive in future years if a marriage breaks up by divorce. As long as the intertemporal price elasticity is below one, both the wealth effect and the price effect due to economies of scale will produce higher saving rates for married couples. As it seems, the positive savings effect of marriage has dominated in the past. ${ }^{3}$ Lupton and Smith (2003) as well as Zissimopoulos (2009) find that married individuals in the U.S. have more than twice the wealth of single individuals on average. In a recent study Sierminska et al. (2010) confirm this result for Germany. They found an average married-single wealth gap of roughly 130 percent. But even if there is a consensus that marriage increases asset accumulation, it is not clear a priori how divorce risk affects the pattern of savings. Since assets of the couple are

3 There are several other effects of marriage that may impact savings decisions. For example, marriage may increase life expectancy and thereby encourage more wealth accumulation. Children in a family should enhance savings as well due to reduced divorce probabilities and bequest motives. 
typically split after a divorce, one would assume that rising divorce risk may reduce saving rates of married couples. However, a recent study by Gonzalez and Özcan (2008) comes to the opposite conclusion. After the introduction of divorce law in Ireland in 1996 divorce rates and consequently divorce risk for married couples rose significantly. While at the same time the Irish savings rate increased significantly stronger than in other European countries, the reaction of the savings rate was especially strong for non-religious married couples who experience the most significant increase in divorce risk. Consequently, Gonzalez and Özcan (2008) argue that divorce risk increases savings. Pericoli and Ventura (2012) derive a similar conclusion analyzing household data for Italy.

Summing up this section, we conclude that there exists significant empirical evidence that changes in household structures affect factor markets. The following section introduces a numerical life-cycle simulation model with families that allows to isolate specific economic effects of changing household structures and to clarify the results from existing empirical studies.

\section{The model economy}

In this section, we describe our model economy. We start with a general overview and afterwards go into mathematical details.

\subsection{Overview}

Our model consists of four interacting sectors: households, firms, the government and the "outside", i.e. the sum of all other countries in the world. We assume a small open economy and let capital be the only mobile factor. Consequently, the economy is a price taker and the capital market interest rate is determined by the world capital market.

At any point in time the household sector is populated by $J$ overlapping generations. We model individuals of both genders, male $M$ and female $F$. At each successive age individuals decide about how much to consume and save. They are endowed with one unit of time, which they can either supply to the market, use for home production or consume as leisure. Beyond a mandatory retirement age $J_{R}$, agents are not allowed to work anymore. Individuals make their choices under a series of risks. Specifically, there is uncertainty about:

(i) future marital status: There are two marital statuses. Individuals are either single or they are married to an individual of the other gender. In the latter case, the married couple constitutes a decision unit with pooled resources, i.e. the two partners make a joint decision about the allocation of consumption, assets, labor supply, home production and leisure consumption. At any age $j$ there is a certain probability $\pi_{j}^{m}$ for a single agents to get married to a single of the other gender. There likewise is a probability $\pi_{j}^{d}$ for a married couple to get divorced. 
(ii) the number of children: Children are another "risk factor" in our model, meaning that their birth also is due to an exogenous probability $\pi^{c}$. Childbirth only takes place at the age $J_{C}$. The kids then live with their parents until they reach adulthood. Children can either be born into a marriage or out of wedlock. In the latter case they will stay with their mother and the father will have to pay alimonies.

(iii) individual labor productivity: Beneath following a gender, age and education dependent trend, individual labor productivity is due to idiosyncratic transitory shocks.

(iv) survival to the next period: Individuals will only survive to the next period with a certain probability $\psi_{j}^{g}$ depending on their gender. Married couples thereby constitute a special case, as it might be that only one of the two partners dies. In this case, the surviving spouse will inherit all the assets of the partner. If both partners die at once or if a single agent dies, they leave accidental bequests to their children's generation.

Figure 4 summarizes the transition of individuals between different marital statuses. For the sake of simplicity, we restrict marriage and divorce to working ages and uncertain survival to the period of retirement. By assumption there is no private insurance market against neither of the risks mentioned above. Agents will therefore have to adapt their individual choices to their current set of economic shocks.

Figure 4: The transition of family status

Marriage and Divorce

Retirement

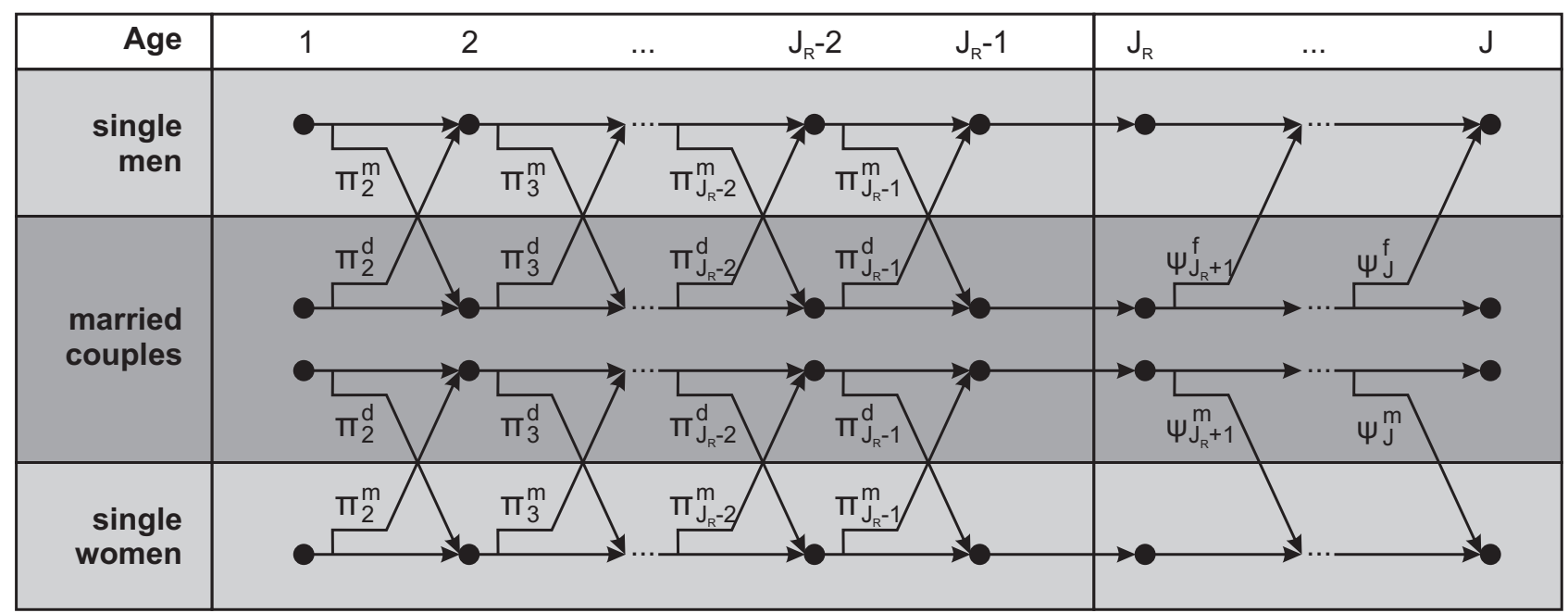

Firms produce a single good under perfect competition employing labor from households and capital from both households and foreign investors. Capital depreciates at a certain rate and firms have to pay corporate taxes on output net of labor and depreciation costs.

The government runs two systems with separate budgets. The tax system collects taxes on individual labor and asset income, consumption and firms' net output in order to finance 
the provision of a public good, child benefit payments as well as interest payments on existing debt. In addition, a pay-as-you-go pension system collects contributions from working agents and pays old-age benefits depending on individuals' earnings history to retirees.

After this very general description of our model, we now define the behavior of all actors in a more technical way.

\subsection{Demographics and intracohort heterogeneity}

At the beginning of each period, a new generation - populated in equal size by men $M$ and women $F-$ is born. Individuals face gender-specific lifespan uncertainty, where $\psi_{j}^{g} \leq 1$ denotes the conditional survival probability of gender $g \in \mathcal{G}=\{M, F\}$ from age $j-1$ to age $j$ with $\psi_{J+1}^{g}=0$.

Our model is solved recursively. The individual state vector of an age- $j$ agent is

$$
z_{j}=\left(g, s, \eta_{j}, m_{j}, \eta_{j}^{*}, k_{j}, a_{j}, p_{j}\right) .
$$

Entries two and three of this vector describe the labor market status of the individual. $s \in$ $\mathcal{S}=\{1, \ldots, S\}$ thereby is agent's skill level and $\eta_{j}$ the idiosyncratic shock to labor income. In case of a married couple, $m_{j}$ and $\eta_{j}^{* 4}$ denote the labor market status of the respective partner. In case the individual is a single we set $m_{j}=\eta_{j}^{*}=0 . k_{j} \in \mathcal{K}=\{0,2\}$ indicates the number of children that have not yet reached adulthood. Finally, $a_{j} \in \mathcal{A}=[0, \infty]$ and $p_{j} \in[0, \infty]$ are agents' beginning of period asset holdings and pension claims.

While assets and pension claims are influenced by individual decisions, the other state variables are determined exogenously. Gender and skill level can be interpreted as one-time persistent shocks, the realization of which is revealed at the beginning of the life-cycle. While the two realizations of gender occur with equal probability, there is a probability distribution $\pi_{g}^{s}$ conditional on gender. As stated in the previous section, marriage and divorce occur at age $j$ with probabilities $\pi_{j}^{m}$ and $\pi_{j}^{d}{ }^{5}$ Yet, we additionally have to define a probability distribution $\pi_{g, s}^{s^{*}}$ indicating the probability of a gender $g$ and skill level $s$ agents to become married to a $s^{*}$ spouse. This probability is conditional on getting married and will be age invariant. Therefore we have $\sum_{S^{*}=1}^{S} \pi_{g, s}^{s^{*}}=1$. Labor market status is transitory and by assumption follows a first-order Markov process. Therefore the probability distribution of future labor productivity $\eta_{j+1}$ only depends on the current labor market status $\eta_{j}$, i.e. there exists a probability distribution $\pi_{g, s}^{\eta}\left(\eta_{j+1} \mid \eta_{j}\right)$ which by assumption depends on gender and skill level. Finally at age $J_{c}$, a fraction $\pi^{c}$ of all men and woman are assigned two children (i.e. $k_{j}=2$ ). Children remain in the household until reaching adulthood, afterwards the household status returns to $k_{j}=0$.

4 Variables with a * indicate variables concerning the spouse.

5 Note that marriage and divorce probabilities in the model are independent of skill-class and do not depend on previous marriage experience. Since divorce probabilities tend to increase in a second or higher-order marriage, this might affect women's labor supply, but only at the intensive and not the extensive margin, see Aughinbaugh (2010). 


\subsection{The household decision problem}

All agents value streams of consumption and leisure according to the standard expected utility function

$$
E\left[\sum_{j=1}^{J} \beta^{j-1} u\left(c_{j}, \ell_{j}\right)\right],
$$

where $\beta$ is a time discount factor. There is no altruism, neither towards the partner in marriage nor towards children. Due to additive separability over time, we can formulate the decision problem recursively. Yet, since individual resources are pooled mandatorily upon marriage and split evenly at divorce, the decision problems of singles and married couples differ slightly.

\subsubsection{The problem of single men and women}

Similar to the static model of Rogerson (2009), the single consumer at age $j$ and state $z_{j}=$ $\left(g, s, \eta_{j}, 0,0, k_{j}, a_{j}, p_{j}\right)$ solves the individual problem

$$
V\left(z_{j}\right)=\max _{x_{j}, h_{j}, \ell_{j}} u\left(c_{j}, \ell_{j}\right)+\beta \psi_{j+1}^{g} E\left[V\left(z_{j+1}\right)\right] .
$$

Individual consumption $c_{j}=c_{j}\left(x_{j}, h_{j}, 0\right)$ is produced within the household by means of market goods $x_{j}$ and home labor $h_{j}$. Since lifespan is uncertain, future utility is weighted with the gender-specific survival probability $\psi_{j+1}^{g}$. Future utility is computed over the distribution of future states of productivity $\eta_{j+1}$, marital status $m_{j+1}$ and $\eta_{j+1}^{*}$ as well as the amount of children $k_{j+1}$. If the agent stayed single with probability $1-\pi_{j+1}^{m}$, his state would move to $z_{j+1}=\left(g, s, \eta_{j+1}, 0,0, k_{j+1}, a_{j+1}, p_{j+1}\right)$. However, if he was to get married to an agent of same age with probability $\pi_{j+1}^{m}$, his future state would change to

$$
z_{j+1}=\left(g, s, \eta_{j+1}, s^{*}, \eta_{j+1}^{*}, k_{j+1}, \frac{a_{j+1}+a_{j+1}^{*}}{2}, \frac{p_{j+1}+p_{j+1}^{*}}{2}\right) .
$$

Single agents take into account the mating probabilities $\pi_{g, s}^{s^{*}}$ and form expectations over future spouses' productivity $\eta_{j+1}^{*}$, assets $a_{j+1}^{*}$ and pension claims $p_{j+1}^{*}$ according to the distribution of singles of gender $g^{*}$ and skill group $s^{*}$ over the state space at age $j$. Note that, if two agents get married, their assets and earning points will be pooled, which highlights the risk sharing aspect of a marriage. ${ }^{6}$

Singles maximize (3) subject to the budget constraint

$$
a_{j+1}=(1+r) a_{j}+y_{j}+\tilde{p}_{j}+c b_{j}+a l_{j}+b_{j}-\tau \min \left[y_{j} ; 2 \bar{y}\right]-T\left(y_{j}, \tilde{p}_{j}, r a_{j}\right)-\left(1+\tau_{x}\right) x_{j}
$$

Agents are endowed with zero assets at the beginning of life $a_{1}=0$ and do not value bequests, i.e. $a_{J+1}=0$. In addition to interest income from savings $r a_{j}$, unmarried individuals

6 The pooling of resources could be a necessary precondition for marriage when marriage partners play a Nash-bargaining game on the wedding day, see Wrede (2003, p. 208). 
receive gross income from supplying labor to the market $y_{j}=w e_{j} \eta_{j} l_{j}$ during their working period as well as public pensions $\tilde{p}_{j}$ during retirement. ${ }^{7} w$ defines the wage rate for effective labor while $e_{j}$ denotes gender- and skill-specific productivity at age $j$. Besides working at home and in the market, all women and married men have to spend time $\varphi_{j}$ on educating their children when those are living in the household. Consequently, market labor is given by $l_{j}=1-h_{j}-\ell_{j}-\varphi_{j}$. The government pays child benefits $c b_{j}$ to mothers. If children were born out of wedlock, fathers have to pay income dependent alimonies $\left(a l_{j}<0\right)$ which are received by the children's mother as a lump-sum payment $\left(a l_{j}>0\right)$. Households may also inherit accidental bequests $b_{j}$ from their parents' generation. They contribute at a rate $\tau$ to the public pension system up to a ceiling which amounts to the double of average income $\bar{y}$. Taxes on labor, pensions and asset income are payed according to the progressive schedule $T(\cdot, \cdot, \cdot)$. Finally, the price of market goods $x_{j}$ includes consumption taxes $\tau_{x}$.

Pension claims are fully earning related. Specifically, they evolve according to

$$
p_{j+1}=p_{j}+\kappa \min \left[y_{j}, 2 \bar{y}\right]
$$

where $\kappa$ denotes the accrual rate, pension claims are earned up to a maximum of twice the average income and $p_{1}=0$.

\subsubsection{The problem of married couples}

We assume a collective model of household decision making. Consequently, married couples of skill groups $s$ and $s^{*}$ at age $j$ maximize a joint welfare function with equal weights in order to obtain efficient outcomes

$$
\max _{x_{j}, h_{j}, h_{j}^{*}, \ell_{j}, \ell_{j}^{*}}\left\{u\left(c_{j}, \ell_{j}\right)+\beta \psi_{j+1}^{g} E\left[V\left(z_{j+1}\right)\right]\right\}+\left\{u\left(c_{j}, \ell_{j}^{*}\right)+\beta \psi_{j+1}^{g^{*}} E\left[V\left(z_{j+1}^{*}\right)\right]\right\}
$$

with $c_{j}=c_{j}\left(x_{j}, h_{j}, h_{j}^{*}\right)$. The respective household budget constraint reflects the fact that both assets and pension claims are pooled within a marriage. ${ }^{8}$ In addition, the income splitting method of family taxation is applied here. Consequently, the household budget constraint reads

$$
\begin{aligned}
2 a_{j+1}=2(1+r) & a_{j}+y_{j}+y_{j}^{*}+2 \tilde{p}_{j}+2 b_{j}+c b_{j} \\
& -\tau\left(\min \left[y_{j} ; 2 \bar{y}\right]+\min \left[y_{j}^{*} ; 2 \bar{y}\right]\right)-2 T\left(\frac{y_{j}+y_{j}^{*}}{2}, \tilde{p}_{j}, r a_{j}\right)-\left(1+\tau_{x}\right) x_{j} .
\end{aligned}
$$

Note again that married couples in our benchmark are not altruistic and don't receive direct utility from being married. Consequently, they still value consumption and leisure according to the function (2).

7 Note that $\tilde{p}_{j}=p_{j}$, if $j \geq J_{R}$ and $\tilde{p}_{j}=0$ otherwise.

8 The pooling of pension claims approximates both the German pension rights adjustment and widow's pension benefit system. 
Beneath the productivity processes for both partners, married agents takes into account three different scenarios: The first of them reflects the situation when the marriage continues with probability $1-\pi_{j+1}^{d}$ in the next period and the spouse survives. In this case, the future state is simply $z_{j+1}=\left(g, s, \eta_{j+1}, s^{*}, \eta_{j+1}^{*}, k_{j+1}, a_{j+1}, p_{j+1}\right)$. The second case covers the situation when one of the spouses dies. In this case the the surviving partner, e.g. the partner of gender $g$, inherits the assets of the partner completely and his state turns into $z_{j+1}=$ $\left(g, s, \eta_{j+1}, 0,0, k_{j+1}, 2 a_{j+1}, p_{j+1}\right)$. Finally, the third case describes the situation when the marriage is divorced. Here, the individual status changes to $z_{j+1}=\left(g, s, \eta_{j+1}, 0,0, k_{j+1}, a_{j+1}, p_{j+1}\right)$, where we assume that assets and pension claims are split equally upon divorce.

\subsection{Instantaneous utility, scale effects, home production and accidental bequests}

The period utility function is defined as

$$
u\left(c_{j}, \ell_{j}\right)=\frac{1}{1-\frac{1}{\gamma}}\left(c_{j}^{1-\frac{1}{\rho}}+\alpha \ell_{j}^{1-\frac{1}{\rho}}\right)^{\frac{1-\frac{1}{\gamma}}{1-\frac{1}{\rho}}}
$$

where $\gamma$ denotes the intertemporal elasticity of substitution between consumption between different ages, $\rho$ defines the intratemporal elasticity of substitution between consumption and leisure at each age $j$ and $\alpha$ is an age-independent leisure preference parameter.

The needs of a household generally do not grow in proportion to the number of household members. We therefore model scale effects in household consumption. Let $n_{j} \in\{1,2\}$ denotes the number of adult household members. Consumption for each adult family member is then derived from

$$
c_{j}\left(x_{j}, h_{j}, h_{j}^{*}\right)=\underbrace{\left(\frac{1}{n_{j}+\phi \hat{k}_{j}}\right)^{\omega}}_{\text {scale effect }} \cdot \underbrace{\left\{v x_{j}^{1-\frac{1}{\chi}}+(1-v) \Phi\left[\left(h_{j}\right)^{1-\frac{1}{\sigma}}+\left(h_{j}^{*}\right)^{1-\frac{1}{\sigma}}\right]^{\frac{1-\frac{1}{\chi}}{1-\frac{1}{\sigma}}}\right\}^{\frac{1}{1-\frac{1}{\chi}}}}_{\text {home production }} .
$$

The production of the consumption good within the household follows a CES home production technology combining market goods $x_{j}$ and aggregate home labor. The latter itself is again derived using a CES production function, where $\sigma$ measures the elasticity of substitution between time spent in home production by the two partners. $v$ is a share parameter for market goods $x_{j}, \Phi$ is a scale parameter and $\chi$ defines the substitution elasticity between market goods $x_{j}$ and effective working time in home production. The function $\Psi$ translates household consumption into consumption realized by each adult family member. The scale effects in household consumption are captured by the parameters $\phi$ and $\omega$. With $0<\phi, \omega<1$ a child costs less than an adult and the second adult and each additional child are cheaper to feed and cloth than the one before. Since children always stay with the mother, single men who have children do not realize child cost in consumption, i.e. $\hat{k}_{j}=0$. 
Our model abstracts from annuity markets. Consequently, private assets of agents who died are aggregated and then distributed equally among all agents of their children's generation. Note, that couples' assets are only passed on to younger cohorts if both partners die at the end of the same period. If a spouse survives, she inherits the complete assets of the partner.

\subsection{The production side}

Firms in this economy use capital and labor to produce a single good according to a CobbDouglas production technology. Capital depreciates at a rate $\delta$ and firms have to pay corporate taxes at rate $\tau_{k}$. Firms maximize profits renting capital and hiring labor from households such that net marginal product of capital equals the interest rate for capital $r$ and the marginal product of labor equals the the wage rate for effective labor $w$, i.e.

$$
\max _{K, L}\left\{\left(1-\tau_{k}\right)\left[\theta K^{\varepsilon} L^{1-\varepsilon}-w L-\delta K\right]-r K\right\}
$$

where $K$ and $L$ are aggregate capital and labor, respectively, $\varepsilon$ is capital's share in production and $\theta$ defines a technology parameter.

\subsection{The government sector}

Our model distinguishes between the tax and the pension system. In each period of the long-run equilibrium, the government collects taxes from households and firms in order to finance general government expenditure $G$ which is fixed per capita as well as interest payments on existing $\operatorname{debt}^{9}$ and child benefits $C B$, i.e.

$$
T_{K}+T_{L}+T_{X}=G+r B_{G}+C B,
$$

where $T_{K}, T_{L}$ and $T_{X}$ define revenues from corporate, income and consumption taxation, respectively. The consumption tax rate balances the budget periodically.

In each period, the pension system pays old-age benefits and collects payroll contributions from labor income below the contribution ceiling of $2 \bar{y}$. The pension budget is balanced in every period by means on the contribution rate.

\subsection{Equilibrium conditions}

In addition to factor prices being equal to marginal products, for a long-run equilibrium, we need households to maximize (3) and (7) with respect to the respective constraints (5) and (8), an invariant distribution of households over the whole state space and market clearance for capital, labor and goods market. Most of the following simulations assume a small open

\footnotetext{
Since we assume a population growth rate of zero, the government can't issue new debt in a long-run equilibrium.
} 
economy with net exports of goods and international capital flows which balance the capital market. $^{10}$

\section{Calibration of the initial equilibrium}

\subsection{Demographic structure}

Table 1 reports the central parameters of the model. In order to reduce computational time, each model period covers five years. Agents reach adulthood at age $20(j=1)$ and may give birth to two children at age $25\left(J_{c}=2\right)$. Since children stay in the household for twenty years, we have $k_{1}=k_{6}=k_{7}=\ldots=0$. Individuals retire mandatorily at age $60\left(J_{R}=9\right)$ and face a maximum possible life span of 100 years $(J=16)$. In order to generate the German average of 1.4 children per mother, we set the childbirth probability $\pi^{\mathcal{c}}=0.7$.

Table 1: Parameter selection

\begin{tabular}{lrlr}
\hline Demographic parameters & \multicolumn{3}{l}{ Preference parameters } \\
\hline (Adult) Life span $(J)$ & 16 & Intertemporal elasticity of substitution $(\gamma)$ & 0.50 \\
Retirement period $\left(J_{R}\right)$ & 9 & Intratemporal elasticity of substitution between & \\
Child birth period $\left(J_{c}\right)$ & 2 & $\ldots$ consumption and leisure $(\rho)$ & 0.60 \\
Childhood periods & 4 & $\ldots$ market goods and home work $(\chi)$ & 0.50 \\
Skill levels $(S)$ & 2 & $\ldots$ male and female home work $(\sigma)$ & 0.90 \\
Childbirth probability $\left(\pi^{c}\right)$ & 0.7 & Coefficient of leisure preference $(\alpha)$ & 0.90 \\
& & Share parameter for market goods $(v)$ & 0.52 \\
& & Scaling factor consumption $(\omega)$ & 0.50 \\
& & Scaling factor children $(\phi)$ & 0.30 \\
& & Discount factor $(\beta)$ & 0.95 \\
\hline Technology/Budget parameters & & Government parameters & 0.60 \\
\hline Factor productivity $(\theta)$ & 1.50 & Debt-to-output $\left(B_{G} / Y\right)$ & 0.20 \\
Capital share $(\varepsilon)$ & 0.35 & Consumption tax rate $\left(\tau_{x}\right)$ & 0.05 \\
Depreciation rate $(\delta)$ & 0.26 & Corporate tax rate $\left(\tau_{k}\right)$ & 0.199 \\
Education time male $\left(\varphi^{m}\right)$ & 0.05 & Contribution rate $(\tau)$ & \\
Education time female $\left(\varphi^{f}\right)$ & 0.175 & & \\
\hline
\end{tabular}

Conditional survival probabilities $\psi_{j}^{g}$ are computed from the year 2000 Life Tables for Germany reported in Bomsdorf (2002). However, in order to simplify the demographic transition, we restrict uncertain survival to retirement years, i.e. $\psi_{j}^{f}=\psi_{j}^{m}=1, j<j_{R}$. We also

10 More information on the equilibrium conditions is available upon request. The computational algorithm is described in Fehr et al. (2008). 
limit (mainly for computational reasons) marriage, divorce and re-marriage to working periods. After retirement, single individuals remain single until death while married couples could only become widows/widowers. Age-specific marriage and divorce probabilities $\pi_{j}^{m}$ and $\pi_{j}^{d}$ are derived from cohort data reported in the Statistical Yearbook of the Statistisches Bundesamt (2007). The left panel of Figure 5 shows the fraction of married women in each cohort we obtain when applying our estimated marriage and divorce probabilities for 2005 to the model. We see an increase of married couples in the early years of life until age 35 due to high marital risk. Passing age 35, the number of married couples stays roughly constant. Finally, with survival probabilities being lower than one at retirement, the fraction of married women again declines as the number of widows/widowers increases. Figure 5 also shows the fraction of married women we obtain when applying estimated probabilities for the 1970ies, i.e. from a time with much more marriages and less divorces. The solid line represents the actual data on married couples in Germany we also computed from Statistisches Bundesamt (2007) data. Of course, this line lies somewhat in between the ones for 1970 and 2005 , since the current household structure of elderly reflects past marital behavior while the model compares two steady states with the 2005 and 1970 probabilities.

Figure 5: Fraction of married women / Estimated wage profiles
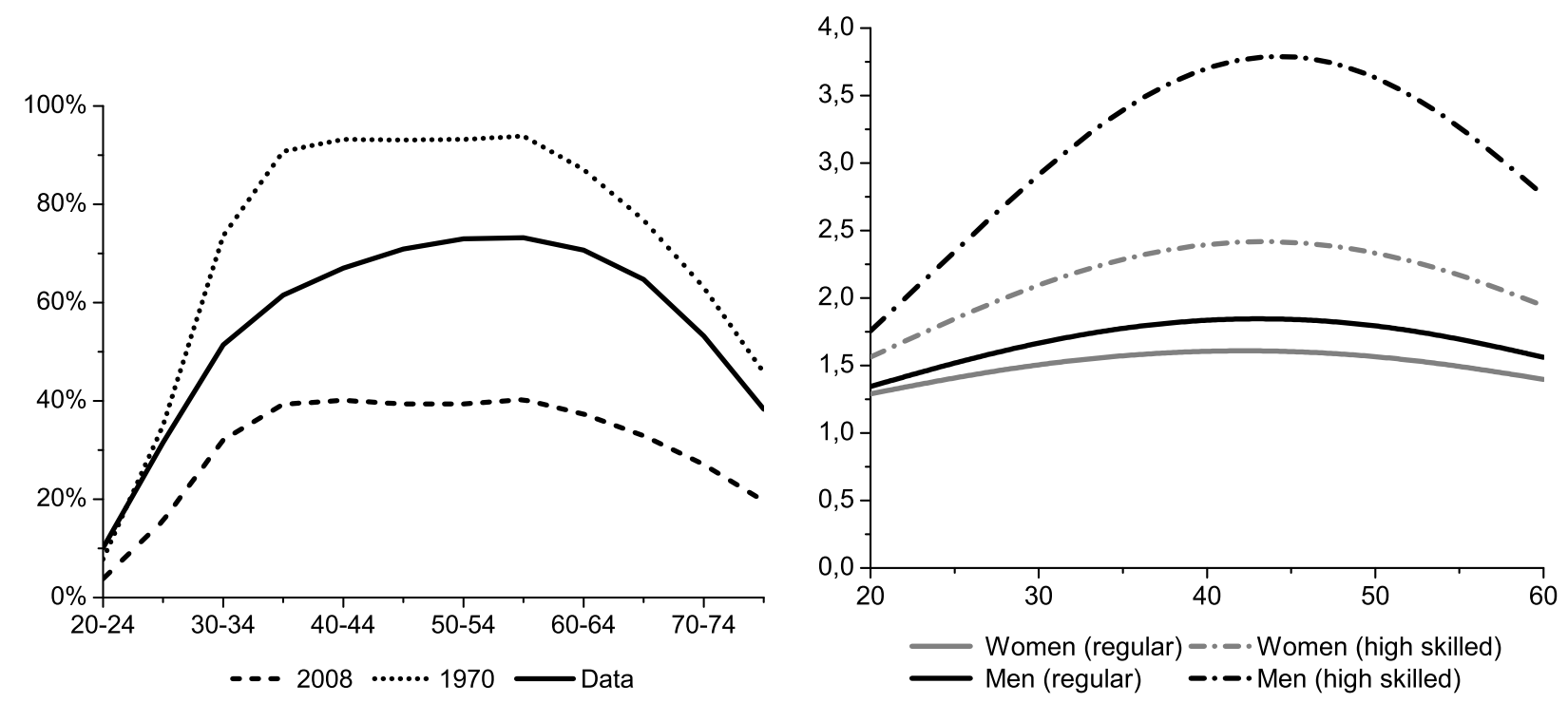

We distinguish high-skilled and low-skilled or regular individuals (i.e. $S=2$ ) and assume that the initial distribution of men and women over these two groups follows the one reported in the appendix. Mating probabilities $\pi_{g, s}^{s^{*}}$ were estimated from German SocioEconomic Panel (SOEP) data of the years 1995-2007 and are reported in the appendix as well. ${ }^{11}$

11 The SOEP data base is described in Wagner et al. (2007). 


\subsection{Preference parameters, labor market participation and time use}

Most microeconomic estimates on the intertemporal elasticity of substitution fall between zero and one, see the discussion in Auerbach and Kotlikoff (1987) or İmrohoroğlu and Kitao (2009). We use in our benchmark $\gamma=0.5$. The intratemporal elasticity of substitution between consumption of goods and leisure is set to $\rho=0.6$, which yields an uncompensated labor supply elasticity for men of 0.12 and for women of 0.22 . Evers et al. (2008) survey labor supply estimates from 30 different studies and find a mean elasticity of 0.07 for men and of 0.34 for woman. Table 2 also illustrates that while single men and women have quite similar labor supply elasticities, married women's labor supply is significantly more elastic than that of men. The latter reflects the fact that labor supply at the extensive margin is more flexible than at the intensive margin for married women. In order to calibrate the participation rates and the split-up of time use, we assume $\chi=0.5$. Rogerson (2009, p. 596) surveys the literature and concludes that typical estimates of the substitution elasticity between market goods and home work lie between 0.4 and 0.6. In addition, we take $\phi=0.3$ and $\omega=0.5$ from Greenwood et al. (2003) to capture the scale effects in household consumption. Then we calibrate the leisure preference parameter $\alpha=0.9$ and the share parameter for market goods $v=0.52$ in order to match realistic overall time use shares for Germany. Burda et al. (2008) report that on average men and women spend about 43.2, 25.5 and 31.2 percent of their time endowment as leisure time, market work and home work, respectively. Next, the intratemporal elasticity of substitution between male and female home work $\sigma=0.9$ is calibrated such that we obtain a time difference in home labor for married men and women reported similar to the one reported in Burda et al. (2008). Here we chose a scaling factor $\Phi$ in order to make sure that aggregate household home labor never exceeds two. Finally, time costs of males and females for the education of children $\varphi_{j}$ are chosen in order to match gender-specific time use data for mothers and fathers reported in Statistisches Bundesamt (2003).

Table 2: Labor supply elasticities in the initial equilibrium*

\begin{tabular}{|c|c|c|c|c|c|c|}
\hline & \multicolumn{2}{|c|}{ Total } & \multicolumn{2}{|c|}{ Single } & \multicolumn{2}{|c|}{ Married } \\
\hline & Men & Women & Men & Women & Men & Women \\
\hline uncompensated & 0.123 & 0.216 & 0.187 & 0.200 & 0.008 & 0.255 \\
\hline compensated & 0.479 & 0.672 & 0.578 & 0.690 & 0.304 & 0.626 \\
\hline
\end{tabular}

Figure 6 compares the fractions of market work, home work and leisure for different marital statuses and genders generated by the model with those from the data. The first block on the left side reveals that men and women spend roughly the same time on leisure consumption, but they are quite different with respect to their shares of market work and home work. Even single men work much less at home then women, which is mainly due to the gender wage gap described below. Specialization increases in a marriage and during the years of child rearing. Note that single mothers work more on the market than married mothers. Finally, 
time spend in home production increases after retirement. On average, retirees devote about 40 percent of their time to home production and 60 percent to leisure consumption.

Figure 6: Time use for specific population groups: model vs. data
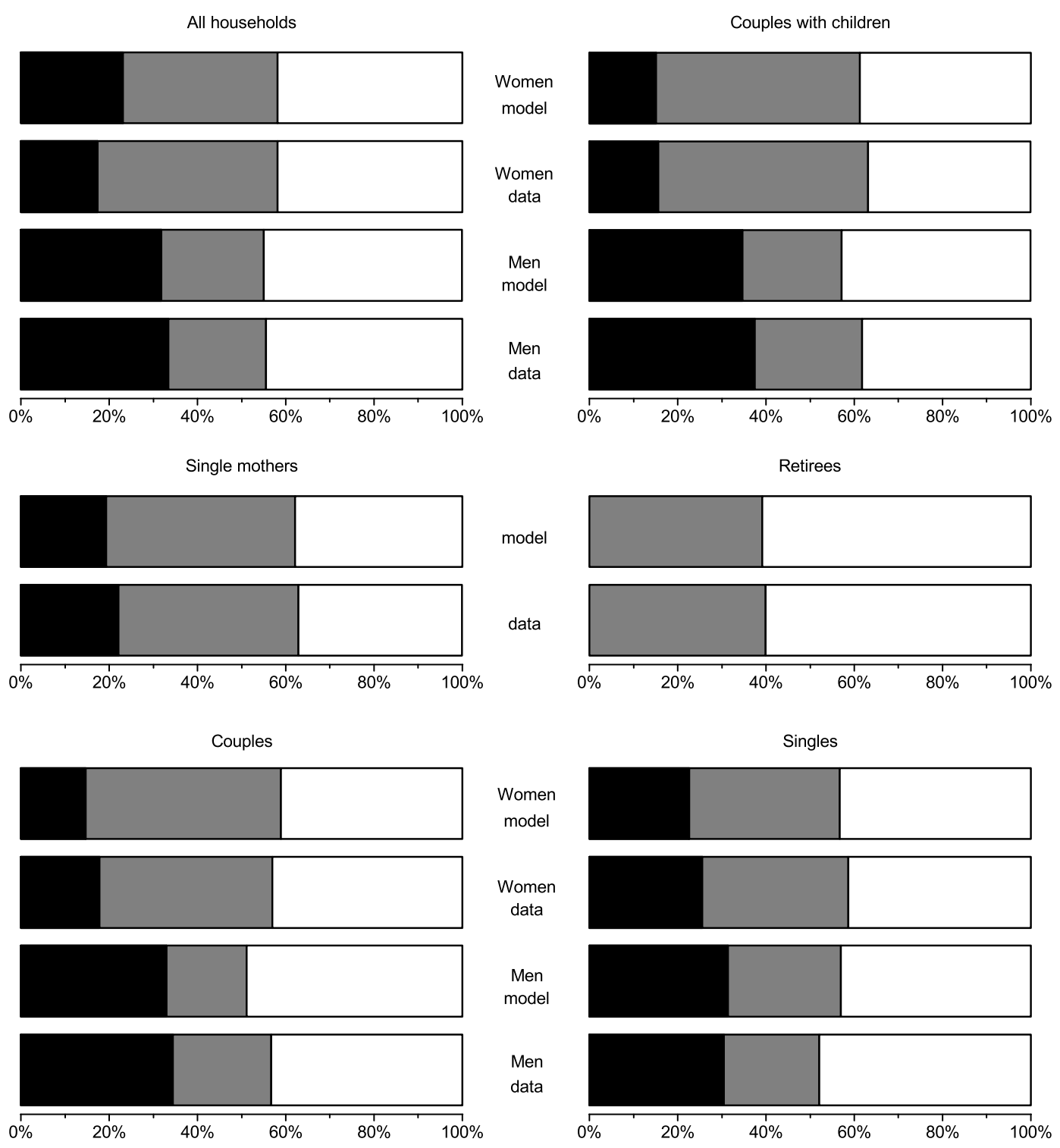

$\square$ Market Work $\square$ Home Work $\square$ Leisure

Source: Burda et al. (2008) and Statistisches Bundesamt (2003).

Finally, in order to calibrate a realistic capital to output ratio of 3.5, the discount factor $\beta$ is set at 0.95 which implies an annual discount rate of about 1 percent.

\subsection{Technology and government parameters}

On the production side we let the capital share in production be $\varepsilon=0.35$ reflecting the average share of capital income in Germany. The annual depreciation rate for capital is 
set at 4.75 percent (i.e. the periodic depreciation rate is $\delta=0.26$ ) which yields a realistic investment share in output. Finally we specify the general factor productivity $\theta=1.5$ in order to normalize the initial wage rate to unity.

We chose an accrual rate $\kappa$ such that the replacement rate of net income amounts to 50 percent, which yields a realistic pension contribution rate for Germany. The progressive income tax schedule is oriented towards German tax practice. Specifically, we let pension contributions be exempt from tax and assume pension benefits to be fully taxed. Taxable labor income is due to gross labor earnings minus a fixed allowance of $2400 €$ per person and an additional deduction of 10 percent of $y_{j}$. The sum of labor and pension income is taxed according to the German tax schedule introduced in 2005. After a basic allowance of 7800 $€$ per person, the marginal tax rate increases from 15.8 to 44.3 percent when taxable income passes $52000 €$. Capital income is taxed at a rate of 26.4 percent after a basic allowance of $9000 €$. The corporate tax rate is set at 5 percent in order to generate a realistic tax revenue. Child benefits $c b_{j}$ reflect current German law which states that on average $2400 €$ are paid as transfers per child ('Kindergeld') by the government. Finally, if parents are not married, the father has to pay an alimony $a l_{j}$ which amounts to 10 percent of his net income per child.

In the initial long-run equilibrium, we assume a debt-to-output ratio of 60 percent and fix the consumption tax rate at 20 percent in order to generate a realistic public consumption ratio $G / Y$.

\subsection{Estimation of productivity profiles and income uncertainty}

We estimate productivity profiles for men and women of different skill classes using inflated hourly wages $w_{i j t}$ of primary household earners from the German SOEP. Our unbalanced panel data covers full-time workers between ages 20 and 60 of the years 1984 to 2006 who were divided into secondary and tertiary educated subgroups according to the International Standard Classification of Education (ISCED) of the UNESCO of 1997. This approach leads us to a total of 130693 observations with 61798 low-skilled males, 49438 low-skilled females, 10636 high-skilled men and 8821 high-skilled women.

With this data, we estimate a simplified version of the Storesletten et al (2004) model. Specifically, we assume log wages to follow a gender, skill group and age dependent trend and let shocks to individual wages to be of $\mathrm{AR}(1)$ type. In addition we estimate time fixed effects to rule out business cycle components and technical change. Consequently we estimate the equations

$$
\log \left(w_{i j t}\right)=e_{j}+\text { time }_{t}+\log \left(\eta_{i j}\right)
$$

with

$$
\log \left(\eta_{i j}\right)=\varrho \log \left(\eta_{i j-1}\right)+\epsilon_{i j}, \quad \epsilon_{i j} \sim N\left(0, \sigma_{\epsilon}^{2}\right) .
$$

We specify the time trend to

$$
e_{j}=\beta_{0}+\beta_{1} \cdot j+\beta_{2} \cdot j^{2} / 100
$$


and estimate four separate equations, one for each gender and skill combination. Our parameter estimates are shown in Table 3 (standard errors are reported in parentheses).

Table 3: Parameter estimates for individual productivity

\begin{tabular}{lccccc}
\hline & \multicolumn{2}{c}{ Men } & & \multicolumn{2}{c}{ Women } \\
\cline { 2 - 3 } \cline { 5 - 6 } & low-skilled & high-skilled & & low-skilled & high-skilled \\
\hline Intercept $\beta_{0}$ & 1.4256 & 06894 & & 1.7944 & 1.4152 \\
& $(0.0351)$ & $(0.1384)$ & & $(0.0397)$ & $(0.1426)$ \\
age term $\beta_{1}$ & 0.0671 & 0.1225 & & 0.0405 & 0.0735 \\
& $(0.0018)$ & $(0.0067)$ & & $(0.0021)$ & $(0.0072)$ \\
age ${ }^{2}$ term $\beta_{2}$ & -0.0721 & -0.1324 & & -0.0459 & -0.0810 \\
& $(0.0023)$ & $(0.0079)$ & & $(0.0027)$ & $(0.0088)$ \\
AR(1) correlation $\varrho$ & 0.8665 & 0.9187 & & 0.8044 & 0.8637 \\
& $(0.0016)$ & $(0.0026)$ & & $(0.0023)$ & $(0.0042)$ \\
transitory variance $\sigma_{\epsilon}^{2}$ & 0.0396 & 0.0380 & & 0.0648 & 0.0556 \\
& $(0.0017)$ & $(0.0070)$ & & $(0.0020)$ & $(0.0062)$ \\
\hline
\end{tabular}

Note that we find a strong $\mathrm{AR}(1)$ correlation of around $0.8-0.9$ for the error term. Bayer and Juessen (2009) document similar values using SOEP data. The estimated wage profiles can be seen in the right part of Figure 5. For computational reasons, we finally approximate the shock $\eta$ by a first order discrete Markov process with three nodes using a discretization algorithm as described in Tauchen (1986). ${ }^{12}$

\subsection{The initial equilibrium}

Table 4 reports the calibrated benchmark equilibrium and the respective figures for Germany in 2010. Since men have lower survival probabilities than women, their life expectancy (at age 20) is 76.8 years, while women on average become 4.3 years older. As one can see, the initial equilibrium reflects quite realistically the current macroeconomic situation in Germany. Note that although our model generates a positive wealth gap between married couples and singles, the actual difference is much lower than the one reported by Sierminska et al. (2010). This is mainly due to a composition effect. Older cohorts have more assets than younger cohorts and in the model the fraction of older married couples is significantly lower than in reality, see Figure 5. In addition, it may also be important that in our model marriage and divorce rates are independent of labor income, whereas in reality rich people have higher marriage rates and more stable marriages than poor people.

12 We have also used a Markov process with five nodes. This approximation yields almost the identical equilibrium but increases computational time dramatically. 
Table 4: The initial equilibrium

\begin{tabular}{|c|c|c|}
\hline & $\begin{array}{c}\text { Model } \\
\text { solution }\end{array}$ & $\begin{array}{r}\text { Germany } \\
2010\end{array}$ \\
\hline \multicolumn{3}{|c|}{ Calibration targets } \\
\hline Total first marriage rate & 0.587 & $0.550^{a}$ \\
\hline Mean age at first marriage (in years) & 31.1 & $29.5 / 32.4^{b}$ \\
\hline Total divorce rate & 0.379 & $0.410^{a}$ \\
\hline Life expectancy (women) (in years) & 81.1 & $81.3^{a}$ \\
\hline Life expectancy (men) (in years) & 76.8 & $76.5^{a}$ \\
\hline Pension benefits (\% of GDP) & 11.8 & $11.6^{c}$ \\
\hline Tax revenues (in \% of GDP) & 21.7 & $22.7^{c}$ \\
\hline Capital-output ratio & 3.5 & $3.5^{c}$ \\
\hline \multicolumn{3}{|c|}{ Other benchmark coefficients } \\
\hline Interest rate p.a. (in \%) & 4.2 & - \\
\hline Bequest (in \% of GDP) & 6.1 & $4.7-7.1^{d}$ \\
\hline from which are intergenerational & 4.2 & - \\
\hline Gini-coefficient for net income & 30.8 & $29.0^{e}$ \\
\hline Wealth-Gap Married/Single (in \%) & 48.7 & $127.9^{f}$ \\
\hline
\end{tabular}

\section{Simulation results}

This section presents our simulation results. In order to quantify the impact of a changing household structure on macroeconomic variables, we compute a new long-run equilibrium that results from the introduction of marriage and divorce probabilities of the 1970s and compare it with the initial equilibrium reported in Table 4 above. However, before we discuss the results from the benchmark model we start with artificial model economies in order to isolate specific insurance, gender and tax effects. Finally we report some sensitivity analysis of the benchmark simulation with respect to central parameters of the model. If not stated otherwise, we always consider a small open economy, where the capital-output ratio of the initial equilibrium from Table 4 remains constant.

For all cases discussed in the following, we assume that both marriage and divorce rates adjust simultaneously. Consequently, the total divorce rate falls to 15.7 percent while the total first marriage rate increases to 99.2 percent. The mean age at first marriage decreases by two years from 31.1 to 29.1 years. All theses figures reflect the situation during the 1970s in Germany, see CEP (2006). 


\subsection{The benchmark scenario}

The left column of Table 5 reports the situation when both genders are completely identical. Males and females have a certain lifespan of 80 years (i.e. $\psi^{g}=1.0$ and $J=12$ ), they are distributed uniformly across both skill-classes, marry only within their own skill class, have no children $\left(\pi^{c}=0.0\right)$, experience no scale effects $(\omega=1.0)$ and face a proportional labor income tax at rate 10.7 percent. $^{13}$

Table 5: Macro effects of family formation: a decomposition ${ }^{a}$

\begin{tabular}{lccccccc}
\hline & $\begin{array}{c}\text { Certain } \\
\text { lifespan } \\
(1)\end{array}$ & $\begin{array}{c}\text { Unisex } \\
\text { mortality } \\
(2)\end{array}$ & $\begin{array}{c}\text { Gender } \\
\text { mortality } \\
(3)\end{array}$ & $\begin{array}{c}\text { Education/ } \\
\text { mating } \\
(4)\end{array}$ & $\begin{array}{c}\text { Scale } \\
\text { effects }\end{array}$ & $\begin{array}{c}\text { Children } \\
(5)\end{array}$ & $\begin{array}{c}\text { Benchmark } \\
\text { case }\end{array}$ \\
\hline Assets $(M)$ & -1.7 & 3.5 & 5.0 & 1.9 & 0.5 & 0.0 & \multicolumn{1}{c}{$(7)$} \\
Assets $(F)$ & -1.7 & 3.5 & 0.0 & 9.4 & 8.5 & 4.6 & 4.3 \\
Market work $(M)$ & 1.0 & 1.9 & -1.3 & 8.6 & 5.2 & 2.7 & 5.4 \\
Market work $(F)$ & 1.0 & 1.9 & 4.9 & -6.3 & -7.5 & -5.1 & -7.2 \\
Home work $(M)$ & 1.3 & -0.1 & -4.6 & -10.6 & -14.7 & -13.6 & -14.9 \\
Home work $(F)$ & 1.3 & -0.1 & 4.4 & 7.6 & 5.7 & 4.3 & 5.4 \\
Output & 1.0 & 1.9 & 1.9 & 2.7 & 0.1 & -0.1 & 0.7 \\
Consumption $\operatorname{tax}^{b}$ & 0.0 & -1.6 & -1.5 & -2.7 & -1.1 & -0.9 & -0.9 \\
\hline
\end{tabular}

${ }^{a}$ In percent of initial equilibrium, ${ }^{b}$ In percentage points.

In this situation both genders react absolutely in the same way when marital risk changes. Now stronger household formation decreases savings quite significantly and increases market work and home work. This result is due to two different behavioral reactions. On the one hand, marriages provide income insurance, so that precautionary savings of singles and couples can be reduced when marriage rates increase and divorce rates fall. On the other hand, singles will also reduce their old-age savings. Since assets are pooled when agents get married and singles take the savings of possible spouses as given, this works like a prisoner's dilemma and leads to a reduction in the purchase of assets. ${ }^{14}$ Consequently, households have to increase labor supply at older ages in order to compensate the savings reduction. Assuming a small open economy, GDP obviously has to move in the same manner as labor supply. The increase in labor supply offsets the fall in interest income, so that income tax revenues remain constant and the consumption tax rate is unaltered.

Next, we introduce lifespan uncertainty in order to quantify the longevity insurance effect. In the second column of Table 5, we assume unisex, averaged survival probabilities that lead to a life expectancy of roughly 80 years for both genders. Since lifespan now is uncertain

13 The case with certain income would be close to the situation analyzed in Cubeddu and Rios-Rull (2003).

14 The same effect is analyzed by Glazer (2008) in a non-cooperative family model. 
and annuity markets are absent, assets of singles and partners that both die in the same period are given as accidental bequests to working generations, whereas surviving spouses receive the whole estate if only one partner dies. Consequently, building up assets in a marriage now provides longevity insurance (Kotlikoff and Spivak, 1981), so that savings now increase compared to the initial equilibrium. In order to finance additional savings households substitute home work for market work, so that labor supply increases. Since income tax revenues increase, the consumption tax rate falls by 1.6 percentage points in order to balance the budget.

In the third column of Table 5, we let survival probabilities differ between genders, i.e. obtain life expectancies as reported in Table 4. In aggregate, i.e. across genders, there is no significant difference to the previous simulation. Yet, we find that assets of men rise while those of women stay constant. This is due to the fact that single women now tend to save more than single men, since their life span is longer. Upon marriage, however, assets are pooled, which causes the above effect. In terms of market and home work, we see that both decrease for men. In consequence, they consume more leisure than in the initial equilibrium. The opposite is the case for women. The reason for this development is that with a higher life expectancy, women now profit much more form a marriage than men, as they are the heirs when their husbands die. In reward for this positive effect, men are allowed to spend more leisure time when married. This is a result of joint welfare maximization.

While the impact on GDP and the tax rate is only modest, there is now a clear difference between the decisions of both genders. On the one side single women work and save more compared to single men, as their expected life span is about 5 years longer. On the other side, married women may receive assets from their husband at old age, which explains the reduction of female assets. Surprisingly on first sight, differential life expectancy also leads to specialization in home production although women have no productivity advantage. The reason is that women can only consume their increased resources at old age if they increase home work as well.

So far, the two genders only differed in mortality rates. However, in reality, there is also some difference in educational backgrounds and mating behavior. In the forth column of Table 5 the uniform skill distribution and strict marriage homogamy is abandoned and the skill distribution and mating matrices from the benchmark simulation of the previous section are applied. Taking a look at those, we notice that men are slightly more skilled than women and, consequently, women tend to marry singles from higher educational classes. Table 5 shows that gender-specific education and marriage behavior has a dramatic effect on specialization of married women in home production. Increased marriage rates now also induce a strongly asymmetric savings reaction. The increase in female savings now mainly reflects the higher asset transfers from men to women after the marriage. At the aggregate level, specialization increases output and income tax revenues significantly.

In column (5) of Table 5 we introduce scale effects in household consumption (i.e. $\omega=0.5$ ). Now marriage alone increases the adult consumption of the couple. As a consequence, when marriage probabilities increase, both partners will consume more leisure and save 
less compared to the previous simulation. The implied reduction in labor supply dampens output growth, so that income tax revenues increase less than before.

Next, we introduce children, child education cost and child benefits in column (6) of Table 5 . Child education cost introduce an additional difference between men and women with kids. Especially single mothers now work less, while single fathers work more than before. Consequently, when marriage rates increase, the specialization towards home work is slightly dampened. In addition, fathers need to spend more time on the education of their children, which explains the smaller labor supply increase compared to the previous simulation. As output is reduced further, so are income tax revenues.

Finally, column (6) of Table 5 reports the benchmark simulation where we now also consider progressive income taxes and income splitting within the marriage. Higher marriage rates now further dampen female labor supply since low-skilled wives face higher marginal tax rates. At the same time marriage increases labor supply of the high-skilled husbands since their marginal tax rate decreases. As marriage reduces tax burdens due to income splitting, progressive income taxation has a positive effect on asset accumulation. The latter balances the revenue losses from labor income taxation, so that the consumption tax rate remains unchanged compared to the previous simulation.

Figure 7: Saving adjustment due to changes in marital risk

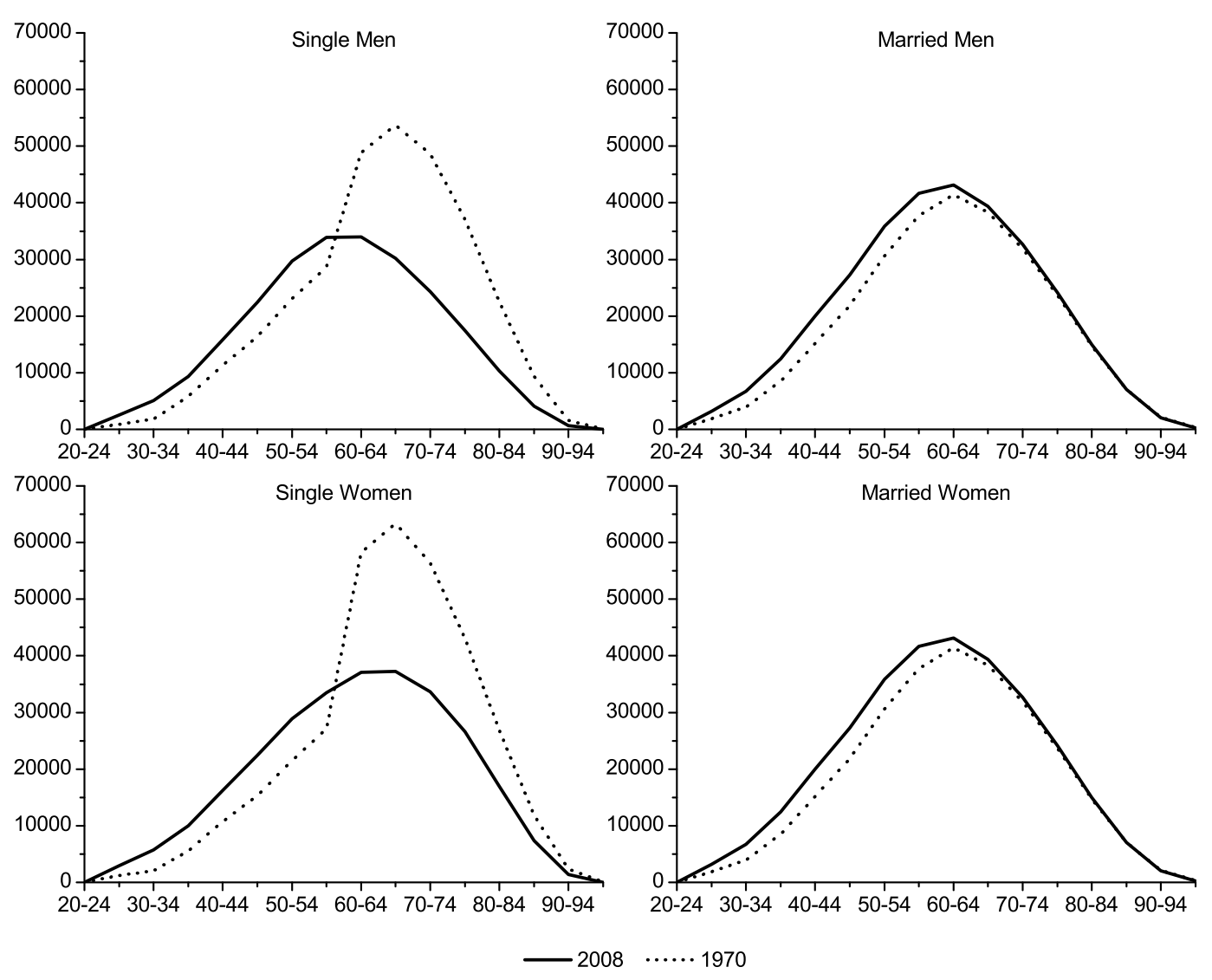

In order to distinguish between behavioral reactions and household composition effects, 
Figures 7 and 8 compare the asset and labor supply profiles over the life cycle for married and single males and females in the benchmark simulation. With respect to asset accumulation, the comparison of married and single households clearly documents the higher saving rates of married households. Even if individual savings behavior would not be affected by marriage probabilities and divorce risk, rising household formation would increase asset accumulation. But Figure 7 also documents significant changes in individual savings behavior. On the left side, young singles reduce their savings when marriage probabilities increase due to the prisoner's dilemma discussed by Glazer (2008). The dramatic increase in assets of older singles simply reflect the fact that surviving spouses inherit all assets. The right side of Figure 7 documents the impact of divorce risk on married couples savings. As already discussed above, our model also captures the empirical finding that higher divorce risk increases precautionary savings.

Similarly, Figure 8 documents the fact that married men work more than single men and vice versa for married and single women. This basically reflects specialization within the marriage. The left part of Figure 8 also documents significant behavioral reactions due to changes in marriage probabilities. Both, single men and women tend to work less when marriage probabilities increase, which again is due to the prisoner's dilemma discussed already before. The right part of Figure 8 documents that rising divorce risk tends to reallocate labor supply of both genders intertemporally, so that market work increases at young ages and decreases later. However, quantitatively the effect of divorce risk on labor supply is only modest.

Summing up the results of this section, we conclude that gender-specific mortality, education and mating as well as the German income tax system are main driving forces of the macro effects reported in the last column of Table 5. The latter are not only due to changes in household composition but also because of behavioral reactions resulting from changes in marital risk.

\subsection{Sensitivity analysis}

This subsection reports the sensitivity of our benchmark results with respect to the parameter specification. In order to isolate risk aversion from intertemporal substitution, we follow the approach of Epstein and Zin (1991) and rewrite the preference structure of the representative consumer as

$$
V\left(z_{j}\right)=\max _{x_{j}, h_{j}, \ell_{j}}\left\{u\left(c_{j}, \ell_{j}\right)+\beta \psi_{j+1}^{g} E\left[V\left(z_{j+1}\right)^{1-v}\right]^{\frac{1-1 / \gamma}{1-v}}\right\}^{\frac{1}{1-\frac{1}{\gamma}}} .
$$

The parameter $v$ defines the degree of (relative) risk aversion. When we apply the special case $v=\frac{1}{\gamma}$, we are back at the traditional expected utility specification discussed above, see Epstein and Zin (1991, p. 266). Consequently, setting relative risk aversion $v=2.0$ yields the benchmark equilibrium reported in the last column of Table 5. Typically, values between 1 and 5 for $v$ are perceived as reasonable in the literature, see Meyer and Meyer (2005). 
Figure 8: Labor supply adjustment due to changes in marital risk

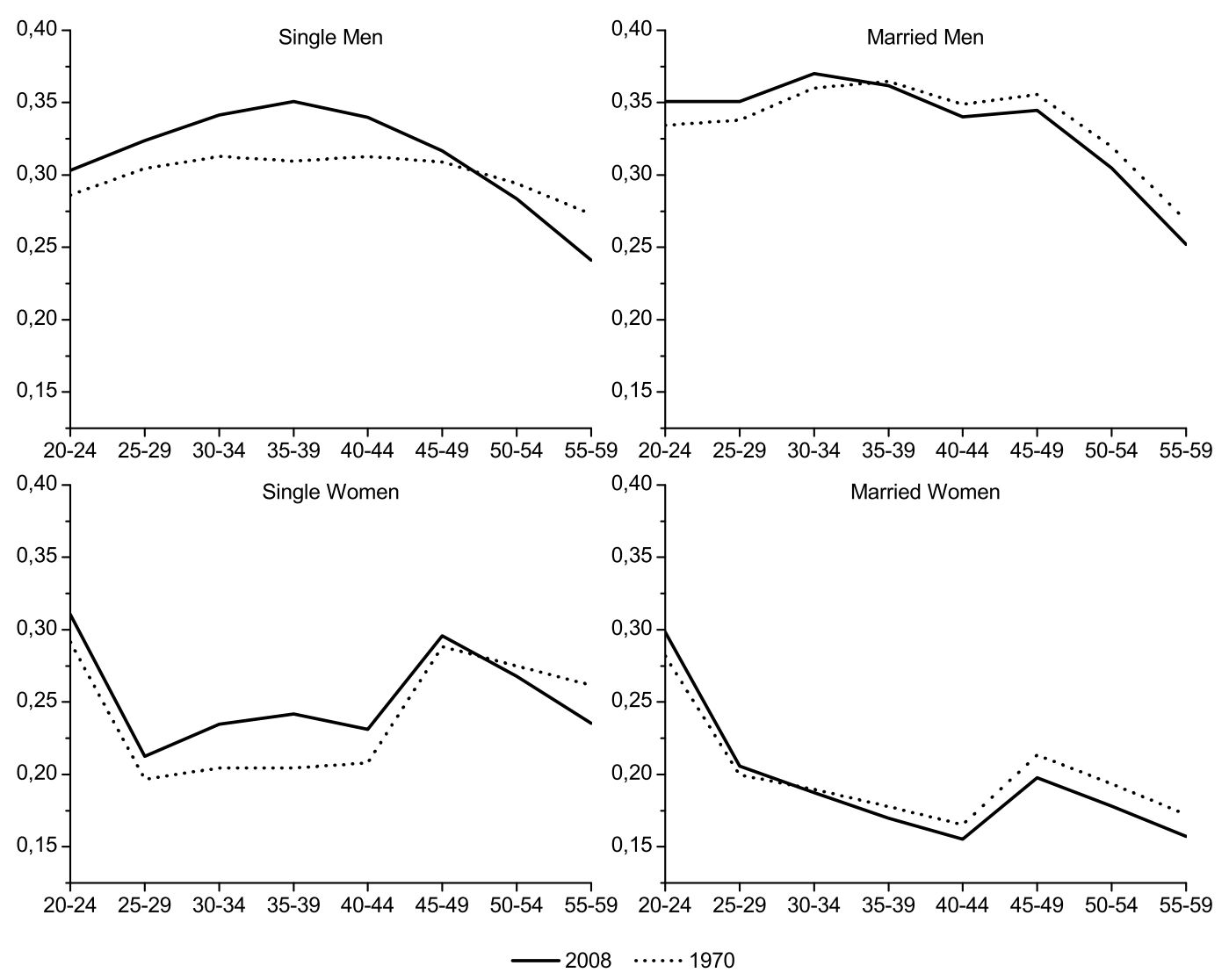

Table 6: Sensitivity analysis of benchmark calibration ${ }^{a}$

\begin{tabular}{lcrrrcc}
\hline & $\begin{array}{c}\text { Benchmark } \\
\text { calibration }\end{array}$ & $\nu=0$ & $\gamma=0.3$ & $\rho=0.8$ & $\begin{array}{c}\omega=0.75 \\
\phi=0.5\end{array}$ & $\begin{array}{c}\text { closed } \\
\text { economy }\end{array}$ \\
\hline Assets $(M)$ & 3.0 & 9.0 & 7.4 & 3.2 & 0.2 & 1.7 \\
Assets $(F)$ & 4.3 & 10.1 & 13.8 & 4.3 & 6.6 & 3.0 \\
Market work $(M)$ & 5.4 & 5.1 & 5.5 & 6.2 & 7.6 & 5.6 \\
Market work $(F)$ & -7.2 & -7.5 & -9.0 & -4.2 & -6.7 & -6.8 \\
Home work $(M)$ & -14.9 & -15.1 & -12.4 & -15.4 & -12.4 & -15.0 \\
Home work $(F)$ & 5.4 & 5.1 & 3.6 & 8.5 & 5.9 & 5.3 \\
Output & 0.7 & 0.4 & 0.2 & 2.3 & 2.3 & 1.6 \\
Consumption tax ${ }^{b}$ & -0.9 & -1.1 & -0.4 & -2.7 & -2.8 & -1.5 \\
\hline
\end{tabular}

${ }^{a}$ In percent of initial equilibrium, ${ }^{b}$ in percentage points.

In the first column of Table 6 we replicate the respective macro effects from the last column of Table 5. Next, we assume an economy with risk neutral individuals (i.e. $v=0$ ) and simulate the change in marital risk with the same capital-output ratio as in Table 4. Since risk neutral agents do not save for precautionary reasons, one of the negative savings effects 
due to higher marriage rates - namely insurance against income uncertainty - disappears. Consequently, rising marriage rates induce higher savings for both genders compared to the benchmark case. However, the labor supply reaction is hardly affected. Setting $v$ back at 2.0 and reducing the intertemporal elasticity of substitution from 0.5 to 0.3 flattens the consumption profile and strengthens liquidity constraints at the beginning of the life cycle. As now there are nearly no savings before singles marry, the prisoner's dilemma caused by asset pooling in marriages is basically absent, which explains why savings increase stronger than in the benchmark. Next, the intratemporal elasticity of substitution is increased, which leads to a stronger specialization in home production and an increase of male and female market work compared to the benchmark simulation. As shown in the following column, the adjustment of scale parameters for household size in order to match OECD-modified equivalence scales hardly affects specialization compared to the benchmark parametrization, while market work of males and females slightly increases. ${ }^{15}$

Overall, Table 6 shows that the reported quantitative figures from the benchmark table are quite robust to parameter changes.

\section{Conclusion}

Summing up the results from the previous section, we have shown that changes in household structure during the last decades may explain at least part of the increase in female labor market participation and the falling participation rates of men in Germany. In addition, our analysis indicates that rising marital risk had dampened aggregate capital accumulation. Although individual savings have increased due to rising marital risk, the negative household composition effect (i.e. more single households, less couples) dominates. Our decomposition highlights, that differences in mortality and education as well as the taxation of couples are the most important determinants of household labor supply when marital risk changes. Finally, we find that changes in household composition also explain at least partly the increase in net income inequality.

Of course, the above analysis could be easily extended to include changes in the skill composition, child birth behavior and/or mortality of both genders since the 1970s. However, this is beyond the scope of the present paper which only concentrates on changes in household composition. In the future we plan to extend the model in various directions. A natural refinement concerns the introduction of a transition path together with a Lump-Sum Redistribution Authority in the spirit of Auerbach and Kotlikoff (1987). This will allow us to simulate policy reforms and analyze their intra- and intertemporal redistribution as well as the aggregate efficiency effects. More specifically, we plan to follow Kaygusuz (2010) or Guner et al. (2012) and simulate the macroeconomic, efficiency and welfare effects of different income tax reforms and family policies in Germany. Since in our model households provide

15 We have also adjusted the elasticity of substitution between home work and market goods $\chi$ but this has only negligible specialization effects. 
some form of income insurance, we can compare optimal tax structures in economies with single households and double earners. In addition, following Hong and Rios-Rull (2007) we also plan to simulate the intergenerational welfare and efficiency consequences of social security privatization. Compared to the traditional model with single individuals, the role of social security becomes unclear when families are taken into account. On the one hand, the benefits of social security from it's provision of longevity insurance (Fehr et al., 2008) will decrease since marriages provide some form of implicit insurance. On the other hand, since marriages may reduce savings in a model with household formation, the introduction of a forced savings system (such as social security) may overcome this savings slump, see Glazer (2008).

Of course, a general drawback of our approach is the assumption that families are modeled as shocks, i.e. there is no real choice about marriage or divorce. Since tax and social security reforms may as well affect household formation, an obvious extension for future work will be to endogenize marriage and divorce probabilities along the lines of Chade and Ventura (2002), Caucutt et al. (2002), Greenwood et al. (2003) and Greenwood and Guner (2009). 


\section{Appendix: Probabilities and skill composition}

Table 7: Age-specific marriage and divorce rates

\begin{tabular}{ccccc}
\hline & \multicolumn{2}{c}{2007} & \multicolumn{2}{c}{1970} \\
Age & $\pi_{j}^{m}$ & $\pi_{j}^{d}$ & $\pi_{j}^{m}$ & $\pi_{j}^{d}$ \\
\hline$(15-19$ & 0.038 & - & 0.078 & $-)$ \\
$20-24$ & 0.143 & 0.491 & 0.307 & 0.147 \\
$25-29$ & 0.249 & 0.291 & 0.641 & 0.087 \\
$30-34$ & 0.194 & 0.187 & 0.807 & 0.056 \\
$35-39$ & 0.098 & 0.131 & 0.649 & 0.039 \\
$40-44$ & 0.049 & 0.091 & 0.352 & 0.027 \\
$45-49$ & 0.035 & 0.053 & 0.236 & 0.016 \\
$50-54$ & 0.031 & 0.027 & 0.212 & 0.008 \\
\hline
\end{tabular}

Table 8: Initial distribution over educational backgrounds

\begin{tabular}{lcc}
\hline Group & $\begin{array}{c}\text { low- } \\
\text { skilled }\end{array}$ & $\begin{array}{c}\text { high- } \\
\text { skilled }\end{array}$ \\
\hline men & 0.765 & 0.235 \\
women & 0.849 & 0.151 \\
\hline
\end{tabular}

Table 9: Mating probabilities $\pi_{g, s}^{s^{*}}$

\begin{tabular}{cccc}
\hline & & \multicolumn{2}{c}{ females } \\
low- & high- \\
skilled & skilled \\
\hline males & low-skilled & 0.966 & 0.034 \\
& high-skilled & 0.467 & 0.533 \\
\hline
\end{tabular}

\begin{tabular}{llcc}
\hline & & \multicolumn{2}{c}{ males } \\
& & low- & high- \\
skilled & skilled \\
\hline \multirow{2}{*}{ female } & low-skilled & 0.871 & 0.129 \\
& high-skilled & 0.172 & 0.828 \\
\hline
\end{tabular}




\section{References}

Attanasio, O., H. Low, and V. Sanchez-Marcos (2005): Female Labor Supply as Insurance against Idiosyncratic Risk, Journal of the European Economic Association 3(2-3), 755-764.

Attanasio, O., H. Low, and V. Sanchez-Marcos (2008): Explaining Changes in Female Labor Supply in a Life-Cycle Model, American Economic Review 98(4), 1517-1552.

Auerbach, A.J. and L.J. Kotlikoff (1987): Dynamic Fiscal Policy, Cambridge University Press, Cambridge.

Aughinbaugh, A. (2010): The Effects of Remarriage on Women's Labor Supply, Journal of Population Economics 23(4), 1151-1176.

Bayer, C. und F. Juessen (2009): The Life-Cycle and the Business-Cycle of Wage Risk: A Cross-Country Comparison, IZA Discussion Paper No. 4402, Bonn.

Bundesinstitut für Bevölkerungsfragen (BiB) (2008): Bevölkerung: Daten, Fakten, Trends zum demographischen Wandel in Deutschland, Wiesbaden.

Bomsdorf, E. (2002): Neue Generationensterbetafeln fu?r die 2 Geburtsjahrga?nge 1933 bis 2003: Modellrechnungen fu? r die Bundesrepublik Deutschland, Eul Verlag, Lohmar.

Burda, M., D. Hamermesh and P. Weil (2008): The Distribution of Total Work in the EU and the USA, in: T. Boeri, M. Burda and F. Kramarz, eds., Working Hours and Job Sharing in the EU and the USA, Oxford University Press, Oxford, 12-91.

Caucutt, E.M., N. Guner and J. Knowles (2002): Why Do Women Wait? Matching, Wage Inequality, and the Incentives for Fertility Delay, Review of Economic Dynamics 5(4), 815855.

Chade, H. and G. Ventura (2002): Taxes and Marriage: A Two-sided Search Analysis, International Economic Review 43(3), 955-985.

Council of Europe Publishing (CEP) (2006): Recent Demographic Developments in Europe 2005, Strasbourg.

Cubeddu, L. and J.V. Ríos-Rull (2003): Families as Shocks, Journal of the European Economic Association 1(2-3), 671-682.

Deutsches Institut für Altersvorsorge (DIA) (2002): Erben in Deutschland, Köln.

Domeij, D. and P. Klein (2002): Public Pensions: To What Extent Do they Account for Swedish Wealth Inequality? Review of Economic Dynamics 5(3), 503-534.

Elvers, M., R. de Mooij and D. van Vuuren (2008): The Wage Elasticity of Labor Supply: A Synthesis of Empirical Estimates, De Economist 156, 25-43. 
Epstein, L.G. and S.E. Zin (1991): Substitution, Risk Aversion, and the Temporal Behavior of Consumption and Asset Returns: An Empirical Analysis, Journal of Political Economy 99(2), 263-286.

Fehr, H., C. Habermann and F. Kindermann (2008): Social Security with Rational and Hyperbolic Consumers, Review of Economic Dynamics 11(4), 884-903.

Glazer, A. (2008): Social Security and Conflict within the Family, Journal of Population Economics 21(2), 331-338.

Gonzalez, L. and B. Özcan (2008): The Risk of Divorce and Household Saving Behavior, IZA Discussion Paper No. 3726, Bonn.

Greenwood, J., N. Guner and J.A. Knowles (2003): More on Marriage, Fertility and the Distribution of Income, International Economic Review 44(3), 827-862.

Greenwood, J. and N. Guner (2009): Marriage and Divorce since World War II: Analyzing the Role of Technological Progress on the Formation of Households, in: D. Acemoglu, K. Rogoff and M. Woodford, eds., NBER Macroeconomics Annual 2008, University of Chicago Press, Chicago, 231-276.

Greenwood, J., A. Seshadri, and M. Yorukoglu (2005): Engines of Liberation, Review of Economic Studies 72(1), 109-133.

Guner, N., R. Kaygusuz, and G. Ventura (2012): Taxation and Household Labor Supply, Review of Economic Studies, forthcoming.

Hong, J.H. and J.-V. Rios-Rull (2007): Social Security, Life Insurance and Annuities for Families, Journal of Monetary Economics 54(1), 118-140.

İmrohoroğlu, S. and S. Kitao (2009): Labor Supply Elasticity and Social Security Reform, Journal of Public Economics 93(7-8), 867-878.

Institut der deutschen Wirtschaft (IdW) (2011): Deutschland in Zahlen, Köln.

Johnson, W.R. and J. Skinner (1986): Labor Supply and Marital Separation, American Economic Review 76(3), 455-469.

Kaygusuz, R. (2010): Taxes and Female Labor Supply, Review of Economic Dynamics 13(4), 725-741.

Kotlikoff, L. und A. Spivak (1981): The Family as an Incomplete Annuities Market, Journal of Political Economy 89(2), 372-391.

Love, D. (2010): The Effects of Martial Status and Children on Savings and Portfolio Choice, Review of Financial Studies, 23(1), 385-432.

Lupton, J.P. and J.P. Smith (2003): Marriage, Assets and Savings, in: S. Grossbard-Shechtman, ed., Marriage and the Economy, Cambridge University Press, 129-152. 
Meyer, D. and J. Meyer (2005): Relative Risk Aversion: What Do We Know? Journal of Risk and Uncertainty 31(3), 243-262.

OECD (2009): Society at a Glance 2009: OECD Social Indicators, OECD, Paris.

OECD (2011a): OECD Family Database, OECD, Paris.

OECD (2011b): The OECD database, available on: stats.oecd.org.

Olivetti, C. (2006): Changes in Women's Hours of Market Work: The Role of Returns to Experience, Review of Economic Dynamics 9(4), 557-587.

Olovsson, C. (2009): Why Do Europeans Work so Little? International Economic Review 50(1), 39-61.

Papps, K.L. (2006): The Effects of Divorce Risk on the Labour Supply of Married Couples, IZA Discussion Paper No. 2395, Bonn.

Pericoli, F. and L. Ventura (2012): Family Dissolution and Precautionary Savings: An Empirical Analysis, Review of Economics of the Household (forthcoming).

Rogerson, R. (2009): Market Work, Home Work, and Taxes: A Cross-Country Analysis, Review of International Economics 17(3), 588-601.

Sachverständigenrat zur Begutachtung der gesamtwirtschaftlichen Entwicklung (SVR) (2009): Die Zukunft nicht aufs Spiel setzen, Jahresgutachten 2009/2010, Wiesbaden.

Sierminska, E.M., J.R. Frick, and M.M. Grabka (2010): Examining the Gender Wealth Gap, Oxford Economic Papers 62(4), 669-690.

Statistisches Bundesamt (2003): Wo bleibt die Zeit? Zeitverwendung der Bevölkerung in Deutschland 2001/02, Wiesbaden.

Statistisches Bundesamt (2007): Statistisches Jahrbuch 2007, Wiesbaden.

Stevenson, B. (2008): Divorce Law and Women's Labor Supply, Journal of Empirical Legal Studies 5(4), 853-873.

Stevenson, B. and J. Wolfers (2007): Marriage and Divorce: Changes and their Driving Forces, Journal of Economic Perspectives 21(2), 27-52.

Storesletten, K., C. I. Telmer and A. Yaron (2004): Consumption and risk sharing over the life cycle, Journal of Monetary Economics 51 (3), 609 ?633.

Tauchen, G. (1986): Finite State Markov-Chain Approximations to Univariate and Vector Autoregressions, Economics Letters 20(2), 177-181.

Wagner, G.G., J.R. Frick and J. Schupp (2007): The German Socio-Economic Panel Study (SOEP) - Scope, Evolution and Enhancements, Journal of Applied Social Science Studies 127(1), 139-169. 
Wrede, M. (2003): The Income Splitting Method: Is it Good for Both Marriage Partners? German Economic Review 4(2), 203-216.

Zissimopoulos, J. (2009): Gain and Loss - Marriage and Wealth Changes over Time, Working Paper 2009-213, Michigan Retirement Research Center. 